\title{
Patient Radiation Risk in Interventional Cardiology
}

Eleni-Theano Samara ${ }^{1 *}$, Abbas Aroua ${ }^{1}$, François Oswald Bochud ${ }^{1}$, Alain Delabays ${ }^{2}$, Jean-Pascal Laedermann ${ }^{1}$ and Francis Robert Verdun ${ }^{1}$

${ }^{1}$ Institute of Radiation Physics, Lausanne University Hospital, Rue du Grand-Pre 1, CH-1007, Lausanne, Switzerland

${ }^{2}$ Department of Cardiology, Lausanne University Hospital, Rue du Bugnon 46, CH-1011 Lausanne, Switzerland

\begin{abstract}
Radiological imaging used in cardiac procedures may result in significant radiation doses to the patient. The aim of this study was to estimate radiation risks from typical cardiac procedures. Monte Carlo simulations were performed to assess absorbed organ doses. Equivalent organ doses and effective doses were calculated using the recommendations in ICRP Publications 60 and $103[1,2]$. The differences in effective dose applying the two recommendations were found to be small. Cancer incidence risks for different organs were calculated for different sex and age at exposure using the lifetime attributable risks provided by the Biological Effects of lonizing Radiations report VII. These results are a straightforward method to comprehend radiation risks.
\end{abstract}

\section{Introduction}

A large increase in both diagnostic and therapeutic interventional procedures has been observed in recent years [3,4]; the most common of them being coronary angiography (CA) and percutaneous coronary intervention (PCI) [4,5]. Cardiac conditions previously treated by open heart surgery may now be safely and effectively performed by $\mathrm{x}$-ray-guided interventions [6]. However, advances in technology have allowed complex cases to be treated leading to longer fluoroscopy times and thus to higher levels of radiation exposure [6,7]. Exposure to $\mathrm{x}$-ray radiation has been demonstrated to increase the risk of cancer $[2,8]$. Thus, the use of radiation in medicine is only accepted when the benefits are greater than the associated risks [2]. Therefore, every procedure that involves exposure to ionizing radiation has to be justified. Before prescribing or performing a radiological procedure for any individual patient, the physician has to weigh the benefits with the risks taking into account the suspected pathology, the characteristics of the patient, alternative medical procedures, etc. The risk-benefit analysis is particularly important for high-dose procedures, such as interventional radiology. Risk assessment is a critical part of the justification process and pertinent quantities have to be used to perform such an evaluation. In addition, radiological procedures need to be optimized on the basis of reliable indicators.

The effective dose (E) as defined by International Commission on Radiological Protection (ICRP) is based on the use of equivalent doses, i.e. mean tissue and organ absorbed doses each weighted by radiation weighting factors which take account of the differences in radio-biological effectiveness of various radiations. Effective dose is the sum of all organ and tissue equivalent doses each weighted by specific tissue weighting factors which are intended to take account of the differences in sensitivity of tissue and organs with respect to stochastic effects. The aim of the $\mathrm{E}$ was to define a radiation protection quantity is which is related to the probability of a detriment from lowdose exposure to ionizing radiation where only stochastic effects occur and which is suited for setting exposure limits and for implementing the optimization principle in the context of occupational and public exposure. The concept of E was adopted by the ICRP 26 (1977) [9] and further developed in its recommendations ICRP 60 (1991) and 103 (2007) [1,2]. E was initially proposed for the radiation protection of the occupational workers and the general public. However, the convenience and ease of evaluating $\mathrm{E}$ in given exposure situations as well as the lack of established methods to estimate patient risks has led to its widespread use in the estimation of patient risks [10]. Yet, publications on awareness of the physicians on radiation protection show that radiation risks are not well understood and assessed [11-
15]. Moreover, it seems that the language of radiation protection is confusing for non-specialists, for instance the use of Sv as unit of both the equivalent organ dose and the effective dose [16,17]. Therefore, there is a need for a quantity that is more dedicated to the assessment of radiation risks, and comprehensive by non-specialists. Equivalent organ dose was intended to quantify the organ risk to assess a certain detriment by multiplying the dose to the organ by the respective risk coefficient [18]. Brenner [16] proposed the use of cancer incidence risks for different organs and tissues provided in the Biological Effects of Ionizing Radiations (BEIR) report VII (NRC 2006) [8] and the estimation of the effective risk (R) [9].

The objective of our study was to examine the possible use of $\mathrm{R}$ as an estimate of radiation risk during common cardiac procedures. To this purpose, two typical cardiac interventional procedures were simulated and the corresponding organ doses and potential risks for cancer induction were estimated.

\section{Materials and Methods}

\section{Patient study}

Patient data were derived from the database of a cardiology department. For our study, data for all the patients referred to CA and PCI procedures during one year were exported. Patient data included patient demographics (sex, weight, height, body mass index (BMI) and age), volume of the contrast agent as well as dose parameters, such as kerma-area product $\left(\mathrm{K}_{\mathrm{AP}}\right)$, fluoroscopy time $(\mathrm{T})$ and cumulative dose $(\mathrm{CD})$ measured at the interventional reference point. The number of images obtained during a procedure was not automatically registered and thus, not included in the database. Patients were divided into different categories according to their BMI (the weight $(\mathrm{kg})$ of the patient divided by the square of the height $\left.\left(\mathrm{m}^{2}\right)\right)$. No patients with a BMI less than 18.5 undergoing a CA or PCI

*Corresponding author: Eleni-Theano Samara, Institute of Radiation Physics Lausanne University Hospital, Rue du Grand-Pre 1, CH-1007, Lausanne, Switzerland, E-mail: eleni-theano.samara@chuv.ch

Received April 12, 2012; Accepted April 23, 2012; Published April 30, 2012

Citation: Samara ET, Aroua A, Bochud FO, Delabays A, Laedermann JP, et al (2012) Patient Radiation Risk in Interventional Cardiology. OMICS J Radiology. 1:103. doi:10.4172/2167-7964.1000103

Copyright: (c) 2012 Samara ET, et al. This is an open-access article distributed under the terms of the Creative Commons Attribution License, which permits unrestricted use, distribution, and reproduction in any medium, provided the original author and source are credited. 
procedure were found. In this study, only data of normal patients were taken into account in order to describe a typical procedure for an average patient. Independent samples Student t-tests were performed to test any differences between a) male and female patients and b) CA and PCI procedures. The statistical analysis was performed with the SPSS software (version 18, SPSS Inc. Chicago, IL).

During a four-month period, a detailed study was performed for the patients referred to CA and PCI procedures. The sample included 32 male and 15 female patients. For these patients technical and physical parameters were recorded, such as source-to-detector distance, number of images acquired during the procedure, tube angulation, and tube voltage $(\mathrm{kV})$ for each series of images. All procedures were performed with a monoplane X-ray unit (Allura Xper FD10, Philips Healthcare, Philips, Eindhoven, Netherlands) equipped with a dynamic flat-panel detector. Pulsed fluoroscopy and cineangiography were used during the procedures.

\section{Monte Carlo simulations}

To estimate organ doses during coronary procedures, Monte Carlo simulations were performed. Monte Carlo simulations are widely used to estimate the radiation dose distribution in the body [19-22]. The general-purpose radiation transport code MCNPX was employed (version 2.5.0, Los Alamos National Laboratory, Los Alamos, NM). This code can handle the transport and interactions of photons, electrons, neutrons and other particles for a wide range of energies and is three-dimensional and time-dependent.

The simulation of the human body was performed using the ICRP 110 voxelized adult reference phantoms [23]. The two phantoms are the official computational models representing the Reference Male and Female. The models are based on computed tomography images of real individuals and represent the human anatomy in three dimensions. The voxel volume for the Reference Male was 36.54 $\mathrm{mm}^{3}$ and that for the Reference Female $15.25 \mathrm{~mm}^{3}$. The phantoms represent an adult male of $73 \mathrm{~kg}$ weight and $1.76 \mathrm{~m}$ height and an adult female of $60 \mathrm{~kg}$ and $1.63 \mathrm{~m}$. All the organs and tissues required for the calculation of the effective dose according to ICRP 103 [2] are included in the phantoms.

Three x-ray spectra $(70,80$ and $90 \mathrm{kVp})$ and $3 \mathrm{~mm} \mathrm{Al}$ total filtration were produced according to the method developed by Boone and Seibert [24]. The distance of the $\mathrm{x}$-ray tube to the detector was assumed to be constant at $100 \mathrm{~cm}$. Five main projections (posterior anterior (PA), right anterior oblique $30^{\circ}\left(\mathrm{RAO} 30^{\circ}\right)$, left lateral (LLAT), left anterior oblique $10^{\circ}\left(\mathrm{LAO} 10^{\circ}\right)$, and left anterior oblique $60 \mathrm{o}$ $\left(\mathrm{LAO} 60^{\circ}\right)$ and three additional ones (right anterior oblique $30^{\circ}$ and caudal $20^{\circ}\left(\mathrm{RAO} 30^{\circ} \mathrm{CAD} 20^{\circ}\right)$, left anterior oblique $10^{\circ}$ and cranial $10^{\circ}\left(\mathrm{LAO} 10^{\circ} / \mathrm{CRA} 10^{\circ}\right)$, and left anterior oblique $60^{\circ}$ and cranial $10^{\circ}$ $\left(\mathrm{LAO} 60^{\circ} \mathrm{CRA} 10^{\circ}\right)$ were studied. For all tube angulations, the field of view was chosen to be $10 \times 10 \mathrm{~cm}^{2}$ centred at the heart of the patient. In all simulations, 200 million histories were performed to ensure that the statistical error was acceptable. Typical CPU time for the simulations varied between 11 and 20 hours on a nine-PC cluster (HP 3646/3GHz/dual core/4Gb RAM, Linux 2.6.32-35-generic, Ubuntu 10.04), depending on the source geometry and energy spectrum.

\section{Verification measurements}

To verify the Monte Carlo results, a physical anthropomorphic phantom (Model 702-D, ATOM, CIRS, Norfolk, VA) that simulates the body trunk of an adult female $1.60 \mathrm{~m}$ in height and $55 \mathrm{~kg}$ in weight was used. The phantom is sectional in design with thirty-eight $25-\mathrm{mm}$ - thick slabs of tissue equivalent material. The tissue-equivalent epoxy resins simulate soft tissue, skeleton and lungs and allow the phantom's use for radiation energies in the field of diagnostic radiology. The phantom provides thermo-luminescent dosimeters (TLDs) locations specific to 21 inner organs. Eighty TLDs were loaded in the phantom in different organs to measure the absorbed dose. The same geometrical setup with that of Monte Carlo simulations was followed to verify the Monte Carlo results. The phantom was exposed to $50 \mathrm{~Gy} \cdot \mathrm{cm}^{2}$ to reduce the statistical errors of the TLD measurements. Normalized organ dose values were calculated as the mean dose gauged by TLDs divided by the total $\mathrm{K}_{\mathrm{AP}}$ for each exposure. Data derived by using TLD dosimetry were compared with corresponding data derived from Monte Carlo simulations.

The TLD crystals (LiF:Mg,Tl chips, TLD-100; Harshaw, Solon, Ohio) were calibrated towards an ionization chamber NE 2575600 $\mathrm{cm}^{3}$ (Nuclear Enterprise, U.K.) connected to an electrometer Keithley 6517A (Keithley Instruments Inc, Cleveland, Ohio) and a Co-60 source (mean energy $1.25 \mathrm{MeV}$ ). The individual sensitivity of each TLD was determined taking into account the energy correction factor calculated by mass energy absorption coefficients. Thus, the overall uncertainty of TLD measurements was lower than 5\%. The TLD reading was performed by a Harshaw 5500 reader system (Harshaw, Solon, Ohio). The annealing process for the TLDs was carried out at a determined oven Hengstler grado 921 (Hengstler GmbH, Aldingen, Germany) for an annealing cycle at $385^{\circ} \mathrm{C}$ for 75 minutes followed by another annealing cycle at $100^{\circ} \mathrm{C}$ for $135 \mathrm{~min}$ in the oven Venticell 222 (MMM Medcenter Einrichtungen GmbH, Munich, Germany). The first annealing cycle is performed for the re-crystallization of the TLDs while the second one is performed to erase the first two peaks of the thermo-luminescent signal, which reduce the dosimeter "fading".

\section{Estimation of effective dose}

The energy deposition to the organs and tissues was estimated using the ${ }^{\star}$ f8-type tally (in MeV). This is a pulse height tally. It is defined by the energy entering a cell (in our case each cell was an organ or tissue) minus the energy leaving this cell for the entire history for each particle emitted by the source. The amount of energy deposited in a cell is the pulse height for that history. A full pulse height spectrum is created when the distribution of the energy deposited by all incident source particles is recorded. The pulse height tally requires the entire set of tracks for a history to be completed. The absorbed dose in the organ or tissue $\left(D_{T}\right)$ was calculated by the energy deposited in the organ or tissue over the corresponding mass $(\mathrm{MeV} / \mathrm{kg})$. $\mathrm{K}_{\mathrm{AP}}$ was also calculated by multiplying the free-in-air-kerma value with the area of the $\mathrm{x}$-ray field. The $\mathrm{K}_{\mathrm{AP}}$-normalized organ dose $\left(D_{T}^{\mathrm{KAP}}\right)$ was calculated by the value of the organ dose divided by the $\mathrm{K}_{\mathrm{AP}}$, as summarized in the equation:

$$
D_{T}^{K A P}=D_{T} / K A P
$$

The $\mathrm{K}_{\mathrm{AP}}$-normalized equivalent dose $\left(H_{T}{ }^{K A P}\right)$ in an organ or tissue was calculated by:

$$
H_{T}^{K A P}=\sum_{R} w_{R} \cdot D_{T, R}^{K A P}
$$

Where the $w_{R}$ is the radiation weighting factor for radiation $\mathrm{R}$, in our case, the radiation weighting factor for the photons was 1 .

$\mathrm{E}$ is based on the mean equivalent doses in organs or tissues of the human body. The tissue weighting factors represent average values for individuals of both sexes. Thus, the equivalent doses in the organs and tissues of the Reference Male and the Reference Female 
were averaged. The averaged equivalent doses were then multiplied with the corresponding tissue weighting factor. The $\mathrm{K}_{\mathrm{AP}}$-normalized effective dose $\left(E^{K A P}\right)$ was calculated as following:

$$
E^{K A P}=w_{\text {breast }} \cdot H_{\text {breast }, \text { Female }}^{K A P}+\sum_{T \neq \text { breast }} w_{T} \cdot\left[H_{T, \text { Male }}^{K A P}+H_{T, \text { Female }}^{K A P} / 2\right]
$$

Where the summation includes the gonads dose (testes in the male and ovaries in the female)

The tissue weighting factors $w_{T}$ are given in table 1 . E was calculated using both ICRP 60 and 103 [1,2]. The new recommendations define the colon and the remainder tissues differently from the old ones and this was also taken into account in the E calculations.

\section{Estimation of effective risk}

The term "effective risk" $\mathrm{R}$ was proposed by [16] in order to estimate the cancer risk from a radiological procedure. $\mathrm{R}$ may be calculated as following:

$$
R=\sum_{T} r_{T} \cdot D_{T}
$$

where $r_{T}$ is the lifetime radiation-attributable tissue- specific cancer risks, as defined by BEIR VII (NRC 2006) [8] and $D_{T}$ is the equivalent dose in tissue $T$. The unit of $\mathrm{R}$ is the cancer incidence. Table 2 shows the risk for cancer incidence according to BEIR VII. The risks are age- and sex-dependent. The dose to "other" $\left(D_{\text {other }}\right.$ was calculated as following:

$$
D_{\text {other }}=\sum_{T} w_{T} \cdot D_{T} / \sum_{T} w_{T}
$$

Where $D_{T}$ is the mean organ dose for a typical cardiac procedure, $w_{T}$ is the tissue weighting factors for the corresponding organs according to ICRP 103 [2]. T concerns the oesophagus, brain, bone surface, skin, salivary glands, the gonads (for male calculations), and the remainder tissue mentioned in ICRP 103 [2] except for the prostate and the uterus.

\begin{tabular}{|l|l|l|}
\hline Organ/Tissue & ICRP 60 & ICRP 103 \\
\hline Gonads & 0.20 & 0.08 \\
\hline Colon & 0.12 & 0.12 \\
\hline Lungs & 0.12 & 0.12 \\
\hline Red bone marrow & 0.12 & 0.12 \\
\hline Stomach & 0.12 & 0.12 \\
\hline Bladder & 0.05 & 0.04 \\
\hline Breast & 0.05 & 0.12 \\
\hline Liver & 0.05 & 0.04 \\
\hline Oesophagus & 0.05 & 0.04 \\
\hline Thyroid & 0.05 & 0.04 \\
\hline Bone surface & 0.01 & 0.01 \\
\hline Skin & 0.01 & 0.01 \\
\hline Brain & & 0.01 \\
\hline Salivary glands & & 0.01 \\
\hline Remainder & $0.05^{\mathrm{a}}$ & $0.01^{\mathrm{b}}$ \\
\hline
\end{tabular}

aCRP 60 remainder organs/tissues: adrenals, brain, kidneys, muscle, pancreas, small intestine, large intestine, spleen, thymus, uterus

bICRP 103 remainder organs/tissues: adrenals, extrathoracic tissue, gall bladder, heart, kidneys, lymphatic nodes, muscle, oral mucosa, pancreas, prostate, smal

\begin{tabular}{|c|c|c|c|c|c|c|}
\hline \multirow[b]{2}{*}{ Cancer site } & \multicolumn{6}{|c|}{ Age at exposure (y) } \\
\hline & 30 & 40 & 50 & 60 & 70 & 80 \\
\hline \multicolumn{7}{|l|}{ Male } \\
\hline Stomach & 28 & 27 & 25 & 20 & 14 & 7 \\
\hline Colon & 125 & 122 & 113 & 94 & 65 & 30 \\
\hline Liver & 22 & 21 & 19 & 14 & 8 & 3 \\
\hline Lung & 105 & 104 & 101 & 89 & 65 & 34 \\
\hline Prostate & 35 & 35 & 33 & 26 & 14 & 5 \\
\hline Bladder & 79 & 79 & 76 & 66 & 47 & 23 \\
\hline Other & 198 & 172 & 140 & 98 & 57 & 23 \\
\hline Thyroid & 9 & 3 & 1 & 0,3 & 0,1 & 0 \\
\hline All solid & 602 & 564 & 507 & 407 & 270 & 126 \\
\hline Leukaemia & 84 & 84 & 84 & 82 & 73 & 48 \\
\hline All cancers & 686 & 648 & 591 & 489 & 343 & 174 \\
\hline \multicolumn{7}{|l|}{ Female } \\
\hline Stomach & 36 & 35 & 32 & 27 & 19 & 11 \\
\hline Colon & 82 & 79 & 73 & 62 & 45 & 23 \\
\hline Liver & 10 & 10 & 9 & 7 & 5 & 2 \\
\hline Lung & 242 & 240 & 230 & 201 & 147 & 77 \\
\hline Breast & 253 & 141 & 70 & 31 & 12 & 4 \\
\hline Uterus & 18 & 16 & 13 & 9 & 5 & 2 \\
\hline Ovary & 34 & 31 & 25 & 18 & 11 & 5 \\
\hline Bladder & 79 & 78 & 74 & 64 & 47 & 24 \\
\hline Other & 207 & 181 & 148 & 109 & 68 & 30 \\
\hline Thyroid & 41 & 14 & 4 & 1 & 0,3 & 0 \\
\hline All solid & 1002 & 824 & 678 & 529 & 358 & 177 \\
\hline Leukaemia & 63 & 62 & 62 & 57 & 51 & 37 \\
\hline All cancers & 1065 & 886 & 740 & 586 & 409 & 214 \\
\hline
\end{tabular}
intestine, spleen, thymus, uterus/cervix

Table 1: Tissue weighting factors wT according to ICRP 60 and 103.
Table 2: Lifetime attributable risk of cancer incidence according to BEIR VII pe 100,000 persons exposed to a single dose of $0.1 \mathrm{~Gy}$.

\section{Results \& Discussion}

\section{Patient characteristics}

In total, 269 patients were included in the study. In table 3, patient demographics, i.e. age, weight, height and BMI, are presented for CA and PCI procedures. Of the 137 patients who underwent a CA procedure, 76 were males and 61 were females with a mean age of 67 years and mean BMI of $22.7 \mathrm{~kg} / \mathrm{m}^{2}$. The 136 patients that underwent PCI procedure were 91 males and 41 females with mean age of 67 years and mean BMI $23.1 \mathrm{~kg} / \mathrm{m}^{2}$.

The parameters related to the patient dose, i.e. $\mathrm{K}_{\mathrm{AP}}$, fluoroscopy time, etc are presented in table 4 and 5 for the CA and PCI procedures, respectively. The mean values for exposure $\left(\mathrm{K}_{A \mathrm{AP}}, \mathrm{T}\right.$, number of images, $\mathrm{CD})$ during CA procedures were found significantly lower than those for PCI procedures ( $p$-values $<0.001$ ). The number of images acquired during the procedures was determined by the sample patient study. This study showed also that the mean tube voltage applied was 77 and $83 \mathrm{kV}$ for CA and PCI procedures, respectively.

\section{Equivalent organ dose}

$\mathrm{K}_{\mathrm{AP}}$-normalized doses for the all organs and tissues recommended by the ICRP were estimated. Tables 6 and 7 present the $\mathrm{K}_{\mathrm{AP}}$-normalized doses for the main organs and the remainder organs and tissues as defined by both ICRP 60 and 103 [1,2]. The heart is included in the remainder organs in ICRP 103; however, we decided to also provide separately the dose to the heart as it is the target organ during the procedures studied.

The $\mathrm{K}_{\mathrm{AP}}$-normalized doses for the colon were calculated with both ICRP 60 and $103[1,2]$ and were found to differ in average by 36 times. 


\begin{tabular}{|l|l|l|}
\hline & CA & PCl \\
\hline Number of patients & 137 & 132 \\
\hline Age $(\mathrm{y})$ & $67 \pm 14(32-93)$ & $67 \pm 12(35-87)$ \\
\hline Sex & $76 \mathrm{M} / 61 \mathrm{~F}$ & $91 \mathrm{M} / 41 \mathrm{~F}$ \\
\hline Weight $(\mathrm{kg})$ & $65 \pm 10(47-97)$ & $67 \pm 9(49-90)$ \\
\hline Height $(\mathrm{m})$ & $1.7 \pm 0.9(1.5-2.0)$ & $1.7 \pm 0.8(1.5-1.9)$ \\
\hline BMI $(\mathrm{kg} / \mathrm{m} 2)$ & $22.7 \pm 1.8(18.8-25)$ & $23.1 \pm 1.6(18.7-25)$ \\
\hline Contrast volume $(\mathrm{ml})$ & $85.3 \pm 43.1(10-320)$ & $173.7 \pm 56.7(50-350)$ \\
\hline
\end{tabular}

Table 3: Patient demographics for $\mathrm{CA}$ and $\mathrm{PCl}$ procedures.

\begin{tabular}{|l|l|l|l|l|l|l|}
\hline & Mean & $\begin{array}{l}\text { Standard } \\
\text { deviation }\end{array}$ & Range & $\begin{array}{l}25^{\text {th }} \\
\text { percentile }\end{array}$ & $\begin{array}{l}50^{\text {th }} \\
\text { percentile }\end{array}$ & $\begin{array}{l}75^{\text {th }} \\
\text { percentile }\end{array}$ \\
\hline $\mathrm{K}_{\mathrm{AP}}\left(\mathrm{Gy} \cdot \mathrm{cm}^{2}\right)$ & 36.7 & 53.4 & $2.0-396$ & 14.0 & 24.6 & 38.2 \\
\hline $\mathrm{T}(\mathrm{min})$ & 5.6 & 4.3 & $1.0-22$ & 2.5 & 4.4 & 7.4 \\
\hline $\begin{array}{l}\text { Number of } \\
\text { images }^{\mathrm{a}}\end{array}$ & 718 & 279 & $303-1,374$ & 508 & 647 & 843 \\
\hline $\mathrm{CD}(\mathrm{mGy})$ & 412 & 295 & $18-2,000$ & 204 & 344 & 545 \\
\hline
\end{tabular}

a Sample study

Table 4: Dose parameters for CA procedures.

\begin{tabular}{|l|l|l|l|l|l|l|}
\hline & Mean & $\begin{array}{l}\text { Standard } \\
\text { deviation }\end{array}$ & Range & $\begin{array}{l}25^{\text {th }} \\
\text { percentile }\end{array}$ & $\begin{array}{l}50^{\text {th }} \\
\text { percentile }\end{array}$ & $\begin{array}{l}75^{\text {th }} \\
\text { percentile }\end{array}$ \\
\hline $\mathrm{K}_{\mathrm{AP}}\left(\mathrm{Gy} \cdot \mathrm{cm}^{2}\right)$ & 65.3 & 43.4 & $9.6-271$ & 36.2 & 54.6 & 81.3 \\
\hline $\mathrm{T}(\mathrm{min})$ & 12.8 & 8.6 & $2.2-63$ & 6.5 & 10.7 & 16.3 \\
\hline $\begin{array}{l}\text { Number of } \\
\text { images }^{\mathrm{a}}\end{array}$ & 1,558 & 834 & $183-3,196$ & 978 & 1,618 & 2,223 \\
\hline $\mathrm{CD}(\mathrm{mGy})$ & 1,059 & 725 & $118-4,813$ & 558 & 923 & 1,374 \\
\hline
\end{tabular}

a Sample study

Table 5: Dose parameters for $\mathrm{PCl}$ procedures.

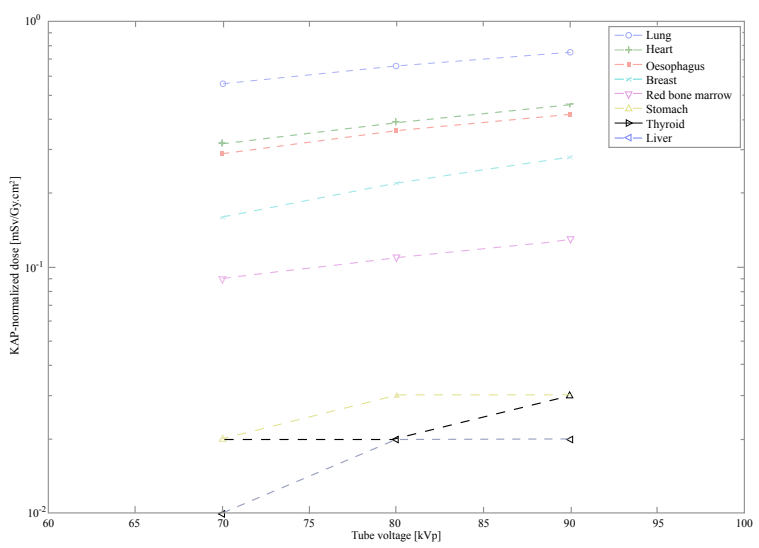

Figure 1: Dependence of eight KAP-normalized organ doses on the tube voltage for $\mathrm{LAO} 10^{\circ}$ projection.

This was expected as the colon according to ICRP 60 was defined as the lower large intestine, but according to ICRP 103 the colon includes also the upper large intestine. The difference in the doses of the remainder tissue was less noticeable. In ICRP 60, the remainder tissue included 10 organs and tissues, while in ICRP 103 by 14 organs (13 for each sex).

The dependence of the organ dose on the tube voltage is presented in figure 1 for the $\mathrm{LAO} 10^{\circ}$ projection. As expected, the higher the tube voltage, the higher the dose. Organs that are inside the $\mathrm{x}$-ray field have higher $\mathrm{K}_{\mathrm{AP}}$-normalized doses, as for example the lungs, the oesophagus and the heart in figure 1. In contrast, organs that lie outside the x-ray field, such as the thyroid, receive lower doses. In

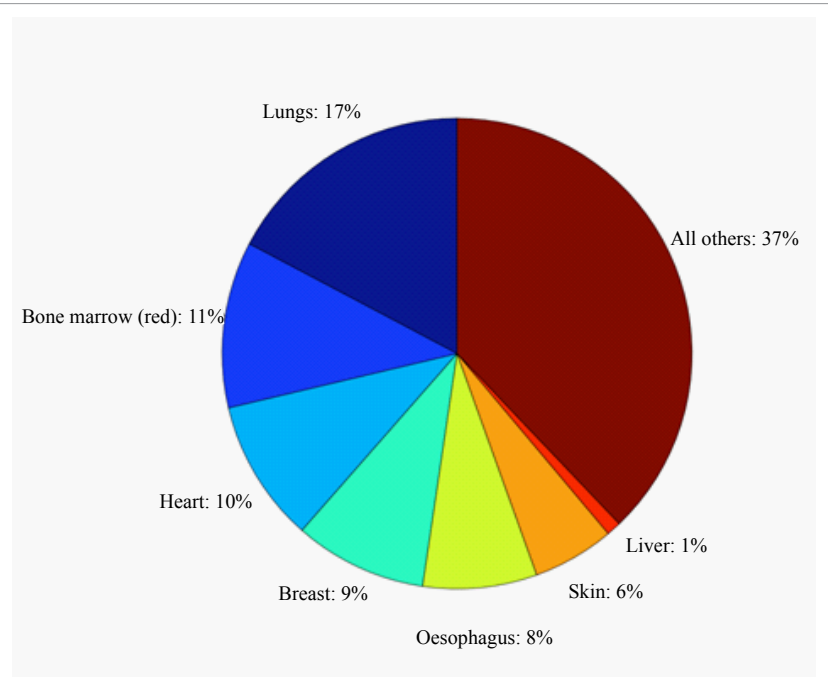

Figure 2: Most irradiated organ and tissues during a typical cardiac procedure.

average the $\mathrm{K}_{\mathrm{AP}}$-normalized doses differ by 1.8 times for tube voltages between 70 and $90 \mathrm{kVp}$. The higher differences (up to 6 times) were observed for low $\mathrm{K}_{\mathrm{AP}}$-normalized doses, such as the case of gonads for $\mathrm{RAO}$ projection. Organs with low $\mathrm{K}_{\mathrm{AP}}$-normalized doses are exposed to scatter radiation; thus, their exposure highly depends on the energy of the scatter radiation.

The $\mathrm{K}_{\mathrm{AP}}$-normalized doses for three tube angulations $\mathrm{RAO} 30^{\circ}$, $\mathrm{LAO} 10^{\circ}$ and $\mathrm{LAO} 60^{\circ}$ were compared to the $\mathrm{RAO} 30^{\circ} \mathrm{CAD} 20^{\circ}$, $\mathrm{LAO} 10^{\circ} / \mathrm{CRA} 10^{\circ}$, and LAO60\% $/ \mathrm{CRA} 10^{\circ}$. A tilt of 10 to 20 degrees in the sagittal plane led to a mean difference of $15 \%$ in organ doses. As expected, the difference in organ doses increases with the angle increase, for instance $30 \%$ difference in the heart dose for RAO30 ${ }^{\circ}$ and $\mathrm{RAO} 30^{\circ} \mathrm{CAD} 20^{\circ}$.

A typical cardiac procedure may be described by the five main projections (PA, $\mathrm{RAO} 30^{\circ}, \mathrm{LAO} 10^{\circ}, \mathrm{LAO} 60^{\circ}$ and LLAT) for $80 \mathrm{kVp}$. The $\mathrm{K}_{\mathrm{AP}}$-normalized doses for the organs and tissues for these angulations were averaged and multiplied by the mean $\mathrm{K}_{\mathrm{AP}}$ values for the CA and PCI procedures. The mean organ doses are presented in table 6. During a typical cardiac intervention, the most irradiated organs were found to be the lungs, heart, red bone marrow, oesophagus and breast, as illustrated in figure 2. Stomach and liver may also receive high doses. A special remark has to be made for the skin dose. The skin dose provided in tables 6-8 concerns the total skin and may be used only for the estimation of the effective dose. In real practice, only a small portion of the skin is directly irradiated at the body entrance. Moreover, skin areas may be irradiated by overlapping x-ray fields and may lead even to skin burns [25]. A quite good indicator for the skin dose is the $\mathrm{CD}$ at the interventional reference point, which is provided in modern X-ray units [26].

$\mathrm{K}_{\mathrm{AP}}$-normalized organ doses were also provided in previous [2729]. An extensive study in cardiac interventional procedures was performed in 1995 by Stern et al. [29]. Schlattl et al. [28] simulated the voxel phantoms Regina and Rex which were then adopted by the ICRP as the Reference Male and Female phantoms. However, differences in the phantom used by Stern et al [29] as well as the tube filtration and voltage, used by [28], do not allow a meaningful comparison between the results. A comparison was possible with the results of Bozkurt and Bor [27] for the male phantom $\mathrm{K}_{\mathrm{AP}}$-normalized organ dose. In this 
Citation: Samara ET, Aroua A, Bochud FO, Delabays A, Laedermann JP, et al. (2012) Patient Radiation Risk in Interventional Cardiology. OMICS J Radiology. 1:103. doi:10.4172/2167-7964.1000103

Page 5 of 9

\begin{tabular}{|c|c|c|c|c|c|c|c|c|c|c|c|c|}
\hline & \multicolumn{3}{|l|}{ PA } & \multicolumn{3}{|l|}{ RAO30 } & \multicolumn{3}{|c|}{ RAO30/CAD20 } & \multicolumn{3}{|l|}{ LLAT } \\
\hline & $70 \mathrm{kVp}$ & $k \vee p$ & $90 \mathrm{kVp}$ & $70 \mathrm{kVp}$ & $0 \mathrm{kVp}$ & $90 \mathrm{kVp}$ & $70 \mathrm{kVp}$ & $80 \mathrm{kVp}$ & $90 \mathrm{kVp}$ & $70 \mathrm{kVp}$ & $80 \mathrm{kVp}$ & $90 \mathrm{kVp}$ \\
\hline Brain & 1.78E-04 & $2.81 \mathrm{E}-04$ & $3.97 \mathrm{E}-04$ & $79 \mathrm{E}-04$ & $34 \mathrm{E}-04$ & $4.10 \mathrm{E}-04$ & $3.31 \mathrm{E}-04$ & $4.98 \mathrm{E}-04$ & 6.87E-04 & $2.48 \mathrm{E}-04$ & $3.88 \mathrm{E}-04$ & $.43 \mathrm{E}-04$ \\
\hline Breast & 1.73E-01 & 2.29E-01 & 2.86E-01 & $1.63 \mathrm{E}-01$ & $21 \mathrm{E}-01$ & 2.79E-01 & $1.38 \mathrm{E}-01$ & $1.90 \mathrm{E}-01$ & 2.43E-01 & $4.29 \mathrm{E}-01$ & 4.96E-01 & $5.62 \mathrm{E}-01$ \\
\hline $\begin{array}{l}\text { one marrow } \\
\text { ed) }\end{array}$ & 2.78E-01 & 3.40E-01 & 3.98E-01 & 8.62E-02 & 1.07E-01 & 1.32E-01 & $9.77 \mathrm{E}-02$ & $1.24 \mathrm{E}-01$ & 1.49E-01 & $5.90 \mathrm{E}-01$ & $6.96 \mathrm{E}-01$ & $8.00 \mathrm{E}-01$ \\
\hline Bone surface & & & & & & & & & & & & \\
\hline Colon 60a & $.07 E-04$ & 33E-04 & 1.80E-04 & 1.03E-04 & 52E-04 & 2.12E-04 & 7.04E-05 & 1.07E-04 & 1.75E-04 & 3.61E-05 & $6.77 \mathrm{E}-05$ & 1.07E-04 \\
\hline Colon 103b & $3.34 \mathrm{E}-03$ & $5.35 \mathrm{E}-03$ & 7.47E-03 & 4.32E-03 & $.78 \mathrm{E}-03$ & 9.39E-03 & $2.74 \mathrm{E}-03$ & $4.44 \mathrm{E}-03$ & 6.37E-03 & $3.67 \mathrm{E}-03$ & $5.59 \mathrm{E}-03$ & $7.81 \mathrm{E}-03$ \\
\hline Oesophag & $.39 \mathrm{E}-01$ & 3.04E-01 & 3.67E- & 2.93E-01 & 01 & & $2.70 \mathrm{E}$ & & & 5.19 & 02 & \\
\hline Gonads & 3.77E-05 & $83 \mathrm{E}-04$ & 2.14E-04 & 2.70E-05 & $.38 \mathrm{E}-04$ & 1.67E-04 & 3.94E-05 & 7.48E-05 & 1.02E-04 & $1.28 \mathrm{E}-04$ & $1.31 \mathrm{E}-04$ & $1.73 \mathrm{E}-04$ \\
\hline iver & $56 \mathrm{E}-02$ & 22E-02 & 2.88E-02 & $1.30 \mathrm{E}-02$ & 1.86E-02 & 2.43E-02 & $1.03 \mathrm{E}-02$ & 1.52E-02 & $\mathrm{E}-02$ & 3.50E-02 & $4.51 \mathrm{E}-02$ & 19E-02 \\
\hline Lung & $.01 \mathrm{E}-01$ & $80 \mathrm{E}-01$ & 5.56E-01 & $5.61 \mathrm{E}-01$ & $.59 \mathrm{E}-01$ & 7.53E-01 & 4.45E-01 & $5.37 \mathrm{E}-01$ & $6.25 \mathrm{E}-01$ & 4.15E-01 & 4.92E-01 & 5.66E-01 \\
\hline Salivary glands & 3.03E-03 & 4.64E-03 & 6.25E-03 & 3.28E-03 & 4.86E-03 & 6.80E-03 & 4.04E-03 & $6.12 \mathrm{E}-03$ & 8.14E-03 & 4.43E-03 & $6.21 \mathrm{E}-03$ & 7.96E-03 \\
\hline Skin & 8.94E-02 & 9.39E-02 & 9.96E-02 & 1.02E-01 & 1.07E-01 & 1.13E-01 & 1.03E-01 & $1.08 \mathrm{E}-01$ & 1.14E-01 & $2.35 \mathrm{E}-01$ & 2.46E-01 & 2.60E-01 \\
\hline Stoma & $1.43 E-02$ & 1.98E-02 & 2.54E-02 & 2.09E-02 & 2.78E-02 & 3.47E-02 & 1.12E-02 & $1.60 \mathrm{E}-02$ & 2.09E-02 & $6.28 \mathrm{E}-03$ & $9.13 \mathrm{E}-03$ & $1.21 \mathrm{E}-02$ \\
\hline Thyroi & $1.60 \mathrm{E}-$ & & & & & & $2.36 \mathrm{E}-02$ & & & $1.05 \mathrm{E}$ & $E-02$ & $\mathrm{E}-02$ \\
\hline Urinary & $2.14 \mathrm{E}-05$ & 3.80E-05 & & $2.28 \mathrm{E}-05$ & & & $1.71 \mathrm{E}-05$ & $2.61 \mathrm{E}-05$ & 4.54E-05 & $2.71 \mathrm{E}-05$ & $5.58 \mathrm{E}-05$ & $6.15 \mathrm{E}-05$ \\
\hline Remainder 60a & 2.27E-01 & 2.95E-01 & 3.66E-01 & 2.69E-01 & 3.47E-01 & 4.23E-01 & 2.16E-01 & $2.78 \mathrm{E}-01$ & 3.43E-01 & $2.91 \mathrm{E}-01$ & 3.48E-01 & 4.07E-01 \\
\hline Remainder $103 b$ & $9.67 \mathrm{E}-01$ & $1.20 \mathrm{E}+00$ & $1.44 \mathrm{E}+00$ & $9.74 \mathrm{E}-01$ & $1.21 \mathrm{E}+00$ & $1.44 \mathrm{E}+00$ & 8.29E-01 & $1.04 \mathrm{E}+00$ & $1.26 \mathrm{E}+00$ & $6.93 \mathrm{E}-01$ & $8.52 \mathrm{E}-01$ & $1.01 \mathrm{E}+00$ \\
\hline Heart & $2.89 \mathrm{E}-01$ & 3.58E-01 & 4.24E-01 & 3.22E-01 & 3.93E-01 & 4.62E-01 & $2.45 \mathrm{E}-01$ & 3.07E-01 & 3.66E-01 & $1.55 \mathrm{E}-01$ & $1.92 \mathrm{E}-01$ & $2.28 \mathrm{E}-01$ \\
\hline
\end{tabular}

${ }^{\text {a }}$ Calculation according to ICRP $60,{ }^{b}$ Calculation according to ICRP 103

Table 6: $\mathrm{K}_{\mathrm{AP}}$-normalized equivalent dose $\left(\mathrm{mSv} / \mathrm{Gy} \cdot \mathrm{cm}^{2}\right)$ as a function of tube voltage and angulations during cardiac interventional procedures.

\begin{tabular}{|c|c|c|c|c|c|c|c|c|c|c|c|c|}
\hline & \multicolumn{3}{|l|}{ LAO10 } & \multicolumn{3}{|c|}{ LAO10/CRA10 } & \multicolumn{3}{|l|}{ LAO60 } & \multicolumn{3}{|c|}{ LAO60/CRA20 } \\
\hline & $70 \mathrm{kVp}$ & $80 \mathrm{kVp}$ & $90 \mathrm{kVp}$ & $70 \mathrm{kVp}$ & $80 \mathrm{kVp}$ & $90 \mathrm{kVp}$ & $70 \mathrm{kVp}$ & $80 \mathrm{kVp}$ & $90 \mathrm{kVp}$ & $70 \mathrm{kVp}$ & $80 \mathrm{kVp}$ & $90 \mathrm{kVp}$ \\
\hline Brain & 1.77E-04 & 2.79E-04 & 4.01E-04 & $1.59 \mathrm{E}-04$ & 2.55E-04 & $3.62 \mathrm{E}-04$ & $2.16 \mathrm{E}-04$ & $3.33 \mathrm{E}-04$ & 4.67E-04 & 1.05E-04 & 1.74E-04 & $2.52 \mathrm{E}-04$ \\
\hline Breast & 1.71E-01 & 2.28E-01 & 2.85E-01 & $1.60 \mathrm{E}-01$ & $2.14 \mathrm{E}-01$ & $2.69 \mathrm{E}-01$ & $7.31 \mathrm{E}-02$ & 1.03E-01 & 1.33E-01 & 6.61E-02 & $9.14 \mathrm{E}-02$ & 1.17E-01 \\
\hline Bone marrow (red) & 3.09E-01 & 3.73E-01 & 4.34E-01 & $3.16 \mathrm{E}-01$ & $3.81 \mathrm{E}-01$ & 4.43E-01 & $6.52 \mathrm{E}-02$ & $8.63 \mathrm{E}-02$ & 1.07E-01 & 4.21E-02 & $5.76 \mathrm{E}-02$ & $7.35 \mathrm{E}-02$ \\
\hline Bone surface & 1.15E-03 & 1.30E-03 & 1.45E-03 & $1.16 \mathrm{E}-03$ & $1.31 \mathrm{E}-03$ & 1.46E-03 & 7.04E-04 & $8.19 \mathrm{E}-04$ & 9.25E-04 & 5.86E-04 & $6.88 \mathrm{E}-04$ & 7.83E-04 \\
\hline Colon 60a & $9.86 \mathrm{E}-05$ & 1.43E-04 & 1.95E-04 & 1.16E-04 & $1.66 \mathrm{E}-04$ & 2.13E-04 & $9.92 \mathrm{E}-05$ & $1.28 \mathrm{E}-04$ & 1.86E-04 & 1.64E-04 & 2.47E-04 & 3.23E-04 \\
\hline Colon 103b & $3.05 \mathrm{E}-03$ & 4.93E-03 & 7.07E-03 & $3.23 \mathrm{E}-03$ & $5.26 \mathrm{E}-03$ & $7.40 \mathrm{E}-03$ & $2.01 \mathrm{E}-03$ & $3.32 \mathrm{E}-03$ & 4.74E-03 & 4.77E-03 & 7.25E-03 & $9.88 \mathrm{E}-03$ \\
\hline Oesophagus & 2.06E-01 & 2.67E-01 & 3.26E-01 & $2.02 \mathrm{E}-01$ & 2.63E-01 & 3.23E-01 & $7.53 \mathrm{E}-02$ & $1.02 \mathrm{E}-01$ & $1.28 \mathrm{E}-01$ & 1.02E-01 & 1.33E-01 & $1.65 \mathrm{E}-01$ \\
\hline Gonads & $1.31 \mathrm{E}-04$ & 1.19E-04 & 2.20E-04 & 1.10E-04 & $1.96 \mathrm{E}-04$ & $1.92 \mathrm{E}-04$ & 6.69E-05 & $1.70 \mathrm{E}-04$ & $2.54 \mathrm{E}-04$ & 1.76E-04 & 2.46E-04 & 4.05E-04 \\
\hline Liver & $1.81 \mathrm{E}-02$ & 2.51E-02 & 3.22E-02 & $1.98 \mathrm{E}-02$ & $2.73 \mathrm{E}-02$ & $3.49 \mathrm{E}-02$ & $2.12 \mathrm{E}-02$ & $2.87 \mathrm{E}-02$ & 3.62E-02 & 8.01E-02 & 9.83E-02 & 1.16E-01 \\
\hline Lung & 3.80E-01 & 4.58E-01 & 5.34E-01 & $3.76 \mathrm{E}-01$ & 4.53E-01 & $5.28 \mathrm{E}-01$ & 2.63E-01 & $3.28 \mathrm{E}-01$ & 3.92E-01 & 3.17E-01 & 3.84E-01 & 4.48E-01 \\
\hline Salivary glands & $2.96 \mathrm{E}-03$ & 4.44E-03 & $6.10 \mathrm{E}-03$ & $2.74 \mathrm{E}-03$ & $4.29 \mathrm{E}-03$ & 5.82E-03 & $2.36 \mathrm{E}-03$ & $3.56 \mathrm{E}-03$ & 4.83E-03 & 1.74E-03 & 2.73E-03 & $3.77 \mathrm{E}-03$ \\
\hline Skin & $9.05 \mathrm{E}-02$ & 9.50E-02 & 1.01E-01 & $9.07 \mathrm{E}-02$ & $9.51 \mathrm{E}-02$ & $1.01 \mathrm{E}-01$ & 2.34E-01 & $2.44 \mathrm{E}-01$ & 2.56E-01 & 2.62E-01 & 2.73E-01 & 2.87E-01 \\
\hline Stomach & $1.18 \mathrm{E}-02$ & 1.68E-02 & 2.19E-02 & $1.27 \mathrm{E}-02$ & $1.79 \mathrm{E}-02$ & 2.33E-02 & $4.01 \mathrm{E}-03$ & $6.16 \mathrm{E}-03$ & 8.47E-03 & 5.03E-03 & 7.58E-03 & $1.03 \mathrm{E}-02$ \\
\hline Thyroid & $1.55 \mathrm{E}-02$ & $2.18 \mathrm{E}-02$ & 2.84E-02 & $1.43 \mathrm{E}-02$ & $2.03 \mathrm{E}-02$ & 2.62E-02 & $9.86 \mathrm{E}-03$ & $1.42 \mathrm{E}-02$ & $1.86 \mathrm{E}-02$ & 8.60E-03 & 1.21E-02 & $1.59 \mathrm{E}-02$ \\
\hline Urinary Bladder & $2.41 \mathrm{E}-05$ & 3.78E-05 & 5.06E-05 & $1.45 \mathrm{E}-05$ & $4.21 \mathrm{E}-05$ & $6.58 \mathrm{E}-05$ & $2.06 \mathrm{E}-05$ & $3.33 \mathrm{E}-05$ & 5.06E-05 & 3.76E-05 & 7.41E-05 & $1.06 \mathrm{E}-04$ \\
\hline Remainder 60a & 2.15E-01 & 2.80E-01 & 3.48E-01 & $2.22 \mathrm{E}-01$ & $2.88 \mathrm{E}-01$ & 3.59E-01 & 2.16E-01 & $2.64 \mathrm{E}-01$ & 3.15E-01 & 3.03E-01 & 3.73E-01 & 4.45E-01 \\
\hline Remainder 103b & $9.24 \mathrm{E}-01$ & $1.15 \mathrm{E}+00$ & $1.38 \mathrm{E}+00$ & $9.10 \mathrm{E}-01$ & $1.14 \mathrm{E}+00$ & $1.37 \mathrm{E}+00$ & $5.15 \mathrm{E}-01$ & $6.48 \mathrm{E}-01$ & 7.82E-01 & 6.46E-01 & 8.04E-01 & $9.62 \mathrm{E}-01$ \\
\hline Heart & $2.58 \mathrm{E}-01$ & 3.22E-01 & $3.85 \mathrm{E}-01$ & $2.55 \mathrm{E}-01$ & 3.19E-01 & 3.82E-01 & 8.07E-02 & 1.07E-01 & 1.34E-01 & $9.35 \mathrm{E}-02$ & $1.22 \mathrm{E}-01$ & $1.50 \mathrm{E}-01$ \\
\hline
\end{tabular}

a Calculation according to ICRP 60, b Calculation according to ICRP 103

Table 7: $\mathrm{K}_{\mathrm{AP}}$-normalized equivalent dose $\left(\mathrm{mSv} / \mathrm{Gy} \cdot \mathrm{cm}^{2}\right)$ as a function of tube voltage and angulations during cardiac interventional procedures.

publication, the voxel VIP-Man phantom was used and simulations were performed for tube voltage from 60 to $120 \mathrm{kVp}$ and a $3.5 \mathrm{~mm} \mathrm{Al}$ filtration. Our results are in a quite good agreement with the results of Bozkurt and Bor [27]. For example, the lung $\mathrm{K}_{\mathrm{AP}}$-normalized dose for $\mathrm{RAO} 30^{\circ}$ projection at $70 \mathrm{kVp}$ in this study was equal to 0.561 $\mathrm{mSv} / \mathrm{Gy} \cdot \mathrm{cm} 2$ and the corresponding value in the Bozkurt and Bor's [27] work was $0.458 \mathrm{mSv} / \mathrm{Gy} \cdot \mathrm{cm}^{2}$. Differences may be attributed to different phantoms and spectrum quality.

Coefficient of variance for large volume organs and organs within the $\mathrm{x}$-ray field, such as liver, lung, skin, heart, etc., was below $0.01 \%$. Although 200 million histories were carried out for each simulation to reduce the statistical errors, coefficients of variance of certain organs remained above $50 \%$, for example left ovary $53 \%$ for $80 \mathrm{kVp}$.

\section{Effective dose}

The $\mathrm{K}_{\mathrm{AP}}$-normalized effective doses according to ICRP 60 (1991) and ICRP 103 (2007) [1,2] for cardiac interventional procedures were calculated and are presented in table 9. The effective doses were found to be higher when using the ICRP 103 than when using ICRP 60. The last column in table 9 shows the ratio of the effective doses between ICRP 103 and ICRP 60. The differences were up to $20 \%$ and were most significant for the tube angulation $\mathrm{LAO} 60^{\circ}$. In the case of cardiac procedures, this is attributed to the breast weighting factor, which was 0.05 in the ICRP 60 and increased to 0.12 in the new recommendations.

Our $\mathrm{K}_{\mathrm{AP}}$-normalized effective doses according to ICRP 60 were found quite lower than published ones (range from 0.09 to $0.24 \mathrm{mSv} /$ 
Citation: Samara ET, Aroua A, Bochud FO, Delabays A, Laedermann JP, et al. (2012) Patient Radiation Risk in Interventional Cardiology. OMICS J Radiology. 1:103. doi:10.4172/2167-7964.1000103

Page 6 of 9

\begin{tabular}{|l|l|l|}
\hline & CA & PCI \\
\hline Brain & $1.15 \mathrm{E}-02$ & $2.04 \mathrm{E}-02$ \\
\hline Breast & $9.37 \mathrm{E}+00$ & $1.67 \mathrm{E}+01$ \\
\hline Bone marrow $($ red) & $1.18 \mathrm{E}+01$ & $2.09 \mathrm{E}+01$ \\
\hline Bone surface & $4.07 \mathrm{E}-02$ & $7.25 \mathrm{E}-02$ \\
\hline Colon & $1.91 \mathrm{E}-01$ & $3.39 \mathrm{E}-01$ \\
\hline Oesophagus & $8.08 \mathrm{E}+00$ & $1.44 \mathrm{E}+01$ \\
\hline Gonads & $5.44 \mathrm{E}-03$ & $9.67 \mathrm{E}-03$ \\
\hline Liver & $1.03 \mathrm{E}+00$ & $1.82 \mathrm{E}+00$ \\
\hline Lung & $1.77 \mathrm{E}+01$ & $3.16 \mathrm{E}+01$ \\
\hline Salivary glands & $1.74 \mathrm{E}-01$ & $3.10 \mathrm{E}-01$ \\
\hline Skin & $5.77 \mathrm{E}+00$ & $1.03 \mathrm{E}+01$ \\
\hline Stomach & $5.85 \mathrm{E}-01$ & $1.04 \mathrm{E}+00$ \\
\hline Thyroid & $7.23 \mathrm{E}-01$ & $1.29 \mathrm{E}+00$ \\
\hline Urinary bladder & $1.41 \mathrm{E}-03$ & $2.52 \mathrm{E}-03$ \\
\hline Remainder organs & $3.72 \mathrm{E}+01$ & $6.61 \mathrm{E}+01$ \\
\hline
\end{tabular}

Table 8: Equivalent organ doses (mSv) for a typical $\mathrm{CA}$ and $\mathrm{PCl}$ procedure (the colon and remainder organ dose estimations were based on ICRP 103).

\begin{tabular}{|c|c|c|c|c|}
\hline Tube angulation & $k \vee p$ & $E_{K A P}-$ ICRP 60 & $E_{\text {KAP }}-$ ICRP 103 & ICRP 103/ICRP60 \\
\hline \multirow[t]{3}{*}{ PA } & 70 & 0.10 & 0.11 & 1.10 \\
\hline & 80 & 0.13 & 0.14 & 1.08 \\
\hline & 90 & 0.15 & 0.17 & 1.13 \\
\hline \multirow[t]{3}{*}{ RAO30 } & 70 & 0.10 & 0.11 & 1.10 \\
\hline & 80 & 0.12 & 0.14 & 1.17 \\
\hline & 90 & 0.14 & 0.16 & 1.14 \\
\hline \multirow{3}{*}{ RAO30/CAD20 } & 70 & 0.09 & 0.10 & 1.11 \\
\hline & 80 & 0.11 & 0.12 & 1.09 \\
\hline & 90 & 0.13 & 0.14 & 1.08 \\
\hline \multirow[t]{3}{*}{ LLAT } & 70 & 0.14 & 0.16 & 1.14 \\
\hline & 80 & 0.17 & 0.19 & 1.12 \\
\hline & 90 & 0.19 & 0.22 & 1.16 \\
\hline \multirow[t]{3}{*}{ LAO10 } & 70 & 0.10 & 0.11 & 1.10 \\
\hline & 80 & 0.13 & 0.14 & 1.08 \\
\hline & 90 & 0.15 & 0.17 & 1.13 \\
\hline \multirow[t]{3}{*}{ LAO10/CRA10 } & 70 & 0.10 & 0.11 & 1.10 \\
\hline & 80 & 0.13 & 0.14 & 1.08 \\
\hline & 90 & 0.15 & 0.17 & 1.13 \\
\hline \multirow[t]{3}{*}{ LAO60 } & 70 & 0.05 & 0.06 & 1.20 \\
\hline & 80 & 0.06 & 0.07 & 1.17 \\
\hline & 90 & 0.08 & 0.09 & 1.13 \\
\hline \multirow[t]{3}{*}{ LAO60/CRA20 } & 70 & 0.06 & 0.06 & 1.00 \\
\hline & 80 & 0.07 & 0.08 & 1.14 \\
\hline & 90 & 0.09 & 0.10 & 1.11 \\
\hline
\end{tabular}

Table 9: $\mathrm{K}_{\mathrm{AP}}$-normalized effective dose $\left(\mathrm{mSv} / \mathrm{Gy} \cdot \mathrm{cm}^{2}\right)$ as a function of tube voltage and source angulations during cardiac interventional procedures.

Gy.cm2), but are in general in good agreement [27]. Any differences may be attributed to the different phantoms and energy spectra used for the simulations. The $\mathrm{K}_{\mathrm{AP}}$-normalized effective doses estimated in this work according to ICRP 103 could not be compared, as to the best of our knowledge, no previous publication estimate effective dose for cardiac procedures according to ICRP 103.

Effective doses for a typical (as previously described) CA and PCI procedure are presented in table 10. Dose calculations were performed for both ICRP 60 and 103. The $\mathrm{K}_{\mathrm{AP}}$-normalized effective doses for 80 $\mathrm{kV}$ were averaged to respect the change in the tube angulation during an actual procedure. The mean $\mathrm{K}_{\mathrm{AP}}$-normalized $\mathrm{E}$ values for ICRP 60 and 103 were found 0.12 and $0.14 \mathrm{mSv} / \mathrm{Gy} \cdot \mathrm{cm} 2$, respectively. This difference is quite small and may be attributed mainly to the increase

\begin{tabular}{|c|c|c|c|c|c|c|c|}
\hline$E(m S v)$ & & Mean & $\begin{array}{l}\text { Standard } \\
\text { deviation }\end{array}$ & Range & $\begin{array}{l}25^{\text {th }} \\
\text { percentile }\end{array}$ & $\begin{array}{l}50^{\text {th }} \\
\text { percentile }\end{array}$ & $\begin{array}{l}75^{\text {th }} \\
\text { percentile }\end{array}$ \\
\hline \multicolumn{8}{|l|}{ ICRP 60} \\
\hline & CA & 4.5 & 6.5 & $0.2-48.3$ & 1.7 & 3.0 & 4.7 \\
\hline & $\mathrm{PCl}$ & 8.0 & 5.3 & $1.2-33.1$ & 4.4 & 6.7 & 9.9 \\
\hline \multicolumn{8}{|c|}{ ICRP103 } \\
\hline & CA & 5.0 & 7.3 & $0.3-53.9$ & 1.9 & 3.3 & 5.2 \\
\hline & $\mathrm{PCl}$ & 8.9 & 5.9 & $1.3-36.9$ & 4.9 & 7.4 & 11.1 \\
\hline
\end{tabular}

Table 10: Effective dose estimation for a typical CA and $\mathrm{PCI}$ procedure.

\begin{tabular}{|l|l|l|l|l|l|l|l|l|l|l|l|l|l|}
\hline \multicolumn{19}{|c|}{ CA } & \multicolumn{7}{c|}{ PCI } \\
\hline $\begin{array}{l}\text { Age at } \\
\text { exposure }\end{array}$ & 30 & 40 & 50 & 60 & 70 & 80 & 30 & 40 & 50 & 60 & 70 & 80 \\
\hline Male & & & & & & & & & & & & \\
\hline Colon & 0 & 0 & 0 & 0 & 0 & 0 & 1 & 1 & 1 & 1 & 0 & 0 \\
\hline Lung & 13 & 13 & 13 & 11 & 8 & 4 & 23 & 23 & 22 & 20 & 14 & 8 \\
\hline Other & 4 & 3 & 3 & 2 & 1 & 0 & 7 & 6 & 5 & 3 & 2 & 1 \\
\hline All solid & 18 & 17 & 16 & 14 & 10 & 5 & 32 & 31 & 29 & 24 & 17 & 9 \\
\hline Leukaemia & 9 & 9 & 9 & 9 & 8 & 5 & 16 & 16 & 16 & 16 & 14 & 9 \\
\hline R & 27 & 26 & 25 & 22 & 18 & 10 & 48 & 47 & 45 & 40 & 31 & 18 \\
\hline Female & & & & & & & & & \\
\hline Lung & 56 & 55 & 53 & 46 & 34 & 18 & 99 & 98 & 94 & 82 & 60 & 31 \\
\hline Breast & 24 & 13 & 7 & 3 & 1 & 0 & 42 & 24 & 12 & 5 & 2 & 1 \\
\hline Other & 11 & 10 & 8 & 6 & 4 & 2 & 20 & 18 & 14 & 11 & 7 & 3 \\
\hline Thyroid & 0 & 0 & 0 & 0 & 0 & 0 & 1 & 0 & 0 & 0 & 0 & 0 \\
\hline All solid & 91 & 79 & 68 & 55 & 39 & 20 & 163 & 140 & 121 & 98 & 69 & 35 \\
\hline Leukaemia & 8 & 8 & 8 & 7 & 6 & 5 & 14 & 14 & 14 & 13 & 12 & 8 \\
\hline R & 99 & 87 & 76 & 63 & 45 & 24 & 177 & 154 & 135 & 111 & 81 & 44 \\
\hline
\end{tabular}

Table 11: Cancer incidence per 100,000 typical CA and $\mathrm{PCl}$ procedures according to age and sex.

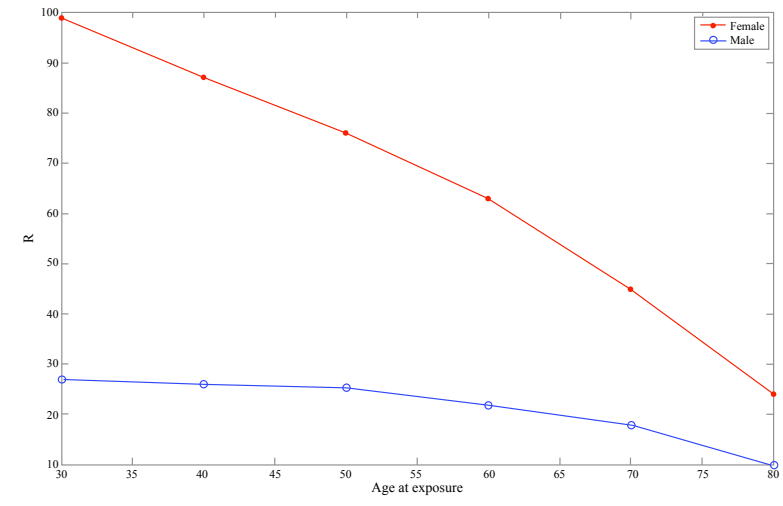

Figure 3: Cancer incidence for a typical CA procedure, as a function of age and sex.

of the breast weighting factor. The $\mathrm{K}_{\mathrm{AP}}$ values from tables 4 and 5 were used to calculate $\mathrm{E}$, resulting to a range from 0.2 to $48.3 \mathrm{mSv}$ for CA procedures and 1.2 to $33.1 \mathrm{mSv}$ for PCI procedures. Effective doses in bibliography ranged between 0.3 to $15.8 \mathrm{mSv}$ for a CA procedure and 0.9 to $44.7 \mathrm{mSv}$ for a PCI procedure [30]. These wide ranges in patient doses may be attributed to the procedure complexity (due to patient anatomy, physician experience, etc.) as well as the different conversion coefficients used for the estimation of the effective dose.

\section{Effective risk}

Organ doses for typical CA and PCI procedures (Table 8) were used to estimate the corresponding risks, according to BEIR VII. Risks for cancer incidence per 100,000 persons are presented in table 11 as a 


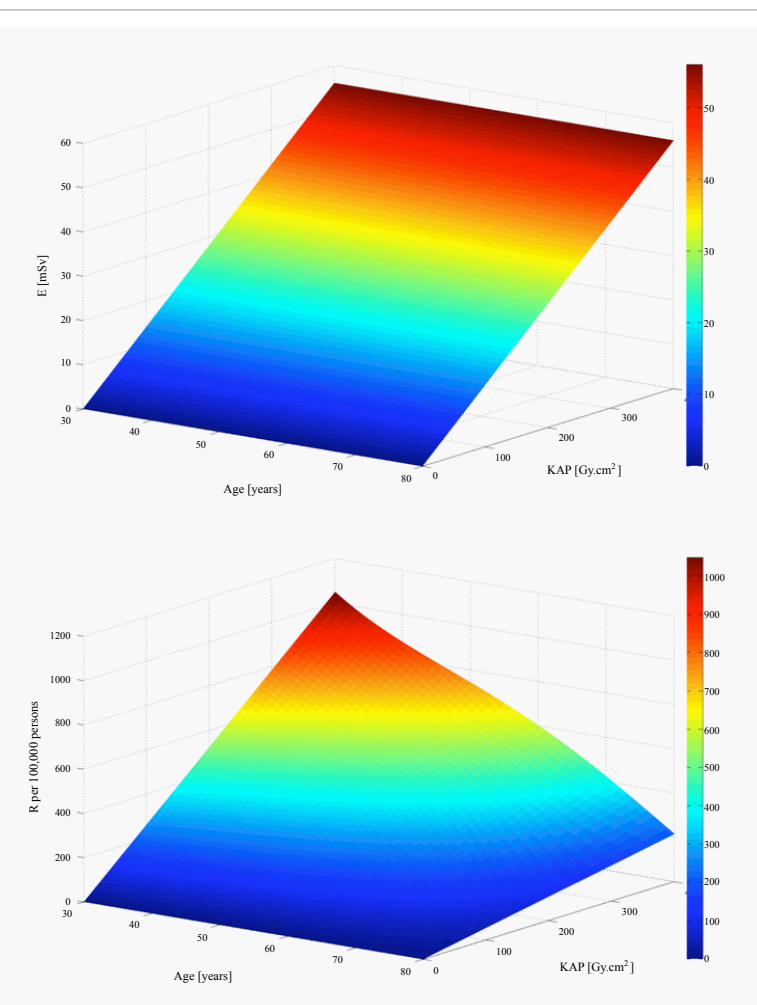

Figure 4: (a) Effective dose (mSv) and (b) cancer incidence risk per 100,000 cardiac procedures (calculations based on female risks) as a function of age (y) and $\mathrm{K}_{\mathrm{AP}}\left(\mathrm{Gy} \cdot \mathrm{cm}^{2}\right)$.

function of age and sex for both procedures. In this table11, the risks for lungs, breast, colon and leukaemia are provided. Risks for organs, such as stomach, liver, urinary bladder, and prostate were found to be very low; thus, not provided in the Table. The estimated risks for "other" were dominated by oesophagus cancer. R was estimated for different age and sex and is provided in the Table. R simply represents the total risk of cancer incidence or mortality. Cancer risks during cardiac procedures are dominated by lung and breast cancer.

Figure 3 illustrates the effective risk for incidence as a function of age and sex for a typical CA procedure. $\mathrm{R}$ is in general greater at younger ages. This may be seen in the figure, where the risk for cancer incidence is five times greater at the age of 30 than that at the age of 70 . Women are more radiation-sensitive than men. Figure 3 shows that $\mathrm{R}$ for a woman is two to five times greater than that of a man who undergoes the same cardiac procedure at the same age, with the difference being more intense at younger ages. This difference is mainly due to the breast and lung cancer risks.

\section{Comparison of effective dose with effective risk}

According to the ICRP $[2,31]$, the purposes of $\mathrm{E}$ in radiation protection for occupational workers and general public are the exposure limitation and prospective dose assessment for optimization and the retrospective dose assessment for demonstrating compliance with dose limits, or for comparing with dose constraints or reference levels. ICRP accepts the use of $\mathrm{E}$ for medical procedures in order to compare the relative risk i) among different procedures, ii) of similar procedures in different hospitals or iii) when using different technologies for the same procedure [31]. However, its use involves a number of assumptions and limitations. Firstly, the tissue weighting factors for the calculation of $\mathrm{E}$ are derived by the risks of cancer incidence, cancer mortality, life shortening and hereditary risks. These risks cannot be combined in one number, as they are rather irrelevant to each other [16]. Moreover, E has been widely used to estimate patient risks Borras et al. [10], as it can be easily converted into an approximate radiation risk, using a risk of fatal cancer of 5\% per Sv averaged over the whole population $[1,2]$. The estimation of excess lifetime risk of developing cancer due to a radiation exposure is more reasonable to be based only on cancer risks. Therefore, the use of R seems more appropriate for such calculations. Some attention should be paid at this point. The obtained results should only be used to compare the relative risk for examinations involving radiation exposure and not to predict number of cancers caused by a medical procedure. Cancer risk estimations for the individual patient is currently impossible due to different patient anatomy which cannot be simulated by the average phantoms, genetic susceptibility to cancer, uncertainties in cancer risk factors, etc.

Secondly, E is defined to be age- and sex- independent. This means that $\mathrm{E}$ does not take into account the age at exposure, although radiation risks are higher for paediatric and young patients than for adults and the fact that women are more radiation-sensitive than men. The most important advantage of $\mathrm{R}$ is that it takes into account different radiation sensitivities among ages and between male and female patients. Our calculations showed that for a typical cardiac procedure the risk of cancer incidence for a 30-year-old male is five times higher than a seventy-year-old and that the cancer incidence risk for a female patient is two times higher than the risk of a male patient (Figure 3). Figure 4 shows the dependence of $\mathrm{E}$ and $\mathrm{R}$ on radiation exposure. The $\mathrm{K}_{\mathrm{AP}}$ goes up to 400 , which is the maximum $\mathrm{K}_{\mathrm{AP}}$ value found in our study. Both $\mathrm{E}$ and $\mathrm{R}$ increase with the increase of the $\mathrm{K}_{\mathrm{AP}}$ While $\mathrm{E}$ remains stable for all ages, $\mathrm{R}$ decreases with patient age. The risk is higher at younger ages (shown in red in Figure $4 \mathrm{~b}$ ).

Thirdly, the use of E may lead to confusion, as both equivalent organ dose and effective dose, which is the weighted sum of equivalent doses, are measured in $\mathrm{Sv}$. The unit of $\mathrm{R}$ is a number of induced cancers per 100,000 procedures. This may eliminate the confusion between organ dose and risk. Comprehension and awareness of radiation risks is particularly important as it allows physicians to balance risks with benefits for each patient. As already discussed, R may be used to estimate the number of induced cancers by medical exposure, while the purpose of the radiation protection is to provide physicians with a way to estimate radiation exposure in order to protect the patient. A wrong interpretation of the results that lead to fear and avoidance of medical exposure is as wrong as the ignorance of potential risks. Referring physicians should understand radiation risks, and be able to explain to patients the potential risks and help them take the right decision. The correct use of radiation protection quantities is useful for the radiation protection of the patient and the good communication between medical physicists, physicians and patients. This becomes more urgent nowadays because the use of radiation in medicine is expanding [4] and modern medicine demands shared decision making between physicians and patients [17]. Therefore, risks due to ionizing radiation have to be put into perspective with other risks (in-hospital complications, false positive or negative results, etc.) and communicated to the patient to get his/her consent.

Examining the practical aspects of $\mathrm{R}$, we found that calculating $\mathrm{R}$ was as complicated as calculating $\mathrm{E}$. The results for $\mathrm{R}$, depending on patient sex and age, may be considered as much more complex and disturbing than the effective dose where only one number is acquired. Although this may be considered as a limitation of $\mathrm{R}$, it provides important information about patient risk and may help 
for deep understanding and active reduction in patient exposure. Changing from $\mathrm{E}$ to $\mathrm{R}$ is difficult, as $\mathrm{E}$ has been extensively used for the estimation of medical exposures. However, we believe that $\mathrm{R}$ is currently the most accurate method of estimating radiation risks. More studies should be performed on how physicians and radiation protection experts perceive the use of $R$.

\section{Limitations of the study}

The first limitation of this study is that the patient study did not allow us to estimate the $\mathrm{K}_{\mathrm{AP}}$ for different angulations of the tube. However, our approximation to consider the contribution of the different angulations as equal may be considered satisfactory in order to simulate a typical cardiac procedure. Another source of error in the estimation of the organ dose is related to variations of organ location and size from the average. Nevertheless, the use of voxelized anthropomorphic phantoms that represent the average patient is the most realistic approach to the issue. Finally, the linear non-threshold model was used to derive risks for low doses from epidemiologic studies on effects of individuals exposed to high levels of ionizing radiation, such as atomic bomb survivors, patients exposed to radiation for medical treatments and animal experiments. This model has been thoroughly argued. However, the main radiation protection organizations and advisory authorities assume that low-radiation doses are associated with hazard risks $[1,4,8]$ and this assumption was also adopted in this study.

\section{Conclusion}

Cardiac procedures can result in considerable radiation doses to the patient, even when performed with modern fluoroscopic equipment. The patient may be exposed to even higher radiation doses due to extended exposure times affected by his clinical condition. Cancer risks cannot be neglected, especially for relatively young patients. Radiation protection needs to be better communicated in order to be well accomplished. Monte Carlo simulations were performed to simulate two typical cardiac procedures. Normalized dose data were derived for the estimation of organ doses. Data provided in this study allow organ dose estimation, regardless of the operating parameters and equipment used. Equivalent organ doses were estimated and the effective dose was calculated using both ICRP recommendations 60 and 103. The differences in effective dose according the two recommendations were found small. Effective dose allows comparisons of the radiation doses among different medical procedures; however it appears to be rather inappropriate for risk communication among specialists and non-specialists. Moreover, effective dose suppresses the effect of age and sex on radiation risk. On the other hand, the effective risk is a straightforward method to communicate and understand radiation risks. We believe that the effective risk is the most accurate method, currently available, to estimate radiation risks. Work still needs to be done, however, to examine how physicians perceive the use of effective risk and the impact of its use in the day-to-day practice.

\section{Acknowledgements}

The authors would like to thank Dr. Hans Menzel for his helpful advice.

\section{References}

1. International Commission on Radiological Protection (1991) 1990 Recommendations of the International Commission on Radiological Protection. ICRP publication 60

2. International Commission on Radiological Protection (2007) Recommendations of the International Commission on Radiological Protection. ICRP publication 103.
3. Samara ET, Aroua A, Bochud FO, Ott B, Theiler T, et al. (2012) Exposure of the Swiss population by medical x-rays: 2008 review. Health Phys 102 263-270.

4. United Nations Scientific Committee on the Effects of Atomic Radiation (2010) UNSCEAR 2008 Report. Sources of Ionizing Radiation, New York United Nations.

5. Samara ET, Aroua A, Bochud FO, Ott B, Theiler T, et al. (2012) Exposure of the Swiss population by medical x-rays: 2008 review. Health Phys 102: 263-270.

6. Balter S, Miller DL, Vano E, Ortiz Lopez P, Bernardi G, et al. (2008) A pilot study exploring the possibility of establishing guidance levels in $\mathrm{x}$-ray directed interventional procedures. Med Phys 35: 673-680.

7. Samara ET, Aroua A, Stauffer JC, Bochud F, Verdun FR (2010) Fluoroscopy-guided procedures in cardiology: is patient exposure being reduced over time? Radiat Prot Dosimetry 139: 271-274.

8. National Research Council (2006) Health risks from Exposure to Low Levels of lonizing Radiation BEIR VII, The National Academies Press, Washington, DC, USA.

9. International Commission on Radiological Protection (1977) Recommendations of the International Commission on Radiological Protection. ICRP publication 26.

10. Borrás C, Huda W, Orton CG (2010) Point/counterpoint. The use of effective dose for medical procedures is inappropriate. Med Phys 37: 3497-3500.

11. Carpeggiani C, Kraft G, Caramella D, Semelka R, Picano E (2011) Radioprotection (un)awareness in cardiologists, and how to improve it. Int $\mathrm{J}$ Cardiovasc Imaging.

12. Wong CS, Huang B, Sin HK, Wong WL, Yiu KL, et al. (2012) A questionnaire study assessing local physicians, radiologists and interns' knowledge and practice pertaining to radiation exposure related to radiological imaging. Eur J Radiol 81: e264-e268.

13. Heyer CM, Hansmann J, Peters SA, Lemburg SP (2010) Paediatrician aware ness of radiation dose and inherent risks in chest imaging studies--a questionnaire study. Eur J Radiol 76: 288-293.

14. Shiralkar S, Rennie A, Snow M, Galland RB, Lewis MH, et al. (2003) Doctors' knowledge of radiation exposure: questionnaire study. BMJ 327: 371-372.

15. Soye JA, Paterson A (2008) A survey of awareness of radiation dose among health professionals in Northern Ireland. Br J Radiol 81: 725-729.

16. Brenner DJ (2008) Effective dose: a flawed concept that could and should be replaced. Br J Radiol 81: 521-523.

17. Picano E (2004) Informed consent and communication of risk from radiological and nuclear medicine examinations: how to escape from a communication inferno. BMJ 329: 849-851.

18. Drexler G, Panzer W, Petoussi N, Zankl M (1993) Effective dose--how effective for patients? Radiat Environ Biophys 32: 209-219.

19. Damilakis J, Perisinakis K, Theocharopoulos N, Tzedakis A, Manios E, et al (2005) Anticipation of radiation dose to the conceptus from occupational exposure of pregnant staff during fluoroscopically guided electrophysiological procedures. J Cardiovasc Electrophysiol 16: 773-780.

20. Damilakis J, Theocharopoulos N, Perisinakis K, Manios E, Dimitriou P, et al. (2001) Conceptus radiation dose and risk from cardiac catheter ablation procedures. Circulation 104: 893-897.

21. Samara ET, Stratakis J, Enele Melono JM, Mouzas IA, Perisinakis K, et al (2009) Therapeutic ERCP and pregnancy: is the radiation risk for the conceptus trivial? Gastrointest Endosc 69: 824-831.

22. Stratakis J, Damilakis J, Hatzidakis A, Perisinakis K, Gourtsoyiannis N (2006) Radiation dose and risk from fluoroscopically guided percutaneous transhepatic biliary procedures. J Vasc Interv Radiol 17: 77-84.

23. International Commission on Radiological Protection (2009) Adult reference computational phantoms. ICRP publication 110

24. Boone JM, Seibert JA (1997) An accurate method for computer-generating tungsten anode x-ray spectra from 30 to $140 \mathrm{kV}$. Med Phys 24: 1661-1670.

25. Valentin J (2000) Avoidance of radiation injuries from medical interventiona procedures. Ann ICRP 30: 7-67. 
Citation: Samara ET, Aroua A, Bochud FO, Delabays A, Laedermann JP, et al. (2012) Patient Radiation Risk in Interventional Cardiology. OMICS J Radiology. 1:103. doi:10.4172/2167-7964.1000103

26. Balter S (2006) Methods for measuring fluoroscopic skin dose. Pediatr Radiol 36: $136-140$

27. Bozkurt A, Bor D (2007) Simultaneous determination of equivalent dose to organs and tissues of the patient and of the physician in interventional radiology using the Monte Carlo method. Phys Med Biol 52: 317-330.

28. Schlattl H, Zankl M, Hausleiter J, Hoeschen C (2007) Local organ dose conversion coefficients for angiographic examinations of coronary arteries. Phys Med Biol 52: 4393-4408.
29. Stern SH, Rosenstein M, Renaud L, ZankI M (1995) Handbook of selected tissue doses for fluoroscopic and cineangiographic examination of the coronary arteries (in SI units). HHS Publication, FDA 95-8289, Rockville, Maryland USA.

30. Pantos I, Patatoukas G, Katritsis DG, Efstathopoulos E (2009) Patient radiation doses in interventional cardiology procedures. Curr Cardiol Rev 5: 1-11.

31. International Commission on Radiological Protection (2009) Radiological protection in medicine. ICRP publication 105

Submit your next manuscript and get advantages of OMICS Group submissions

Unique features:

- User friendly/feasible website-translation of your paper to 50 world's leading languages

Audio Version of published paper

Digital articles to share and explore

Special features:

200 Open Access Journals

15,000 editorial team

21 days rapid review process
Quality and quick editorial, review and publication processing

Quality and quick editorial, review and publication processing
Indexing at PubMed (partial), Scopus, DOAJ, EBSCO, Index Copernicus and Google Scholar etc - Indexing at PubMed (partial), Scopus, DOAJ,

Authors, Reviewers and Editors rewarded with online Scientific Credits

Authors, Reviewers and Editors rewarded
Better discount for your subsequent articles

Submit your manuscript at: http://www.omicsonline.org/submission 